\title{
Postharvest ultraviolet-C (UV-C) treatment reduces decay and maintains quality of bell peppers
}

\author{
Işılay KARAŞAHİN YILDIRIM1', Mustafa PEKMEZCi'²
}

${ }^{1}$ Batı Akdeniz Agricultural Research Institute, ANTALYA

${ }^{2}$ Akdeniz University, Faculty of Agriculture, Department of Horticulture, ANTALYA

Alınış tarihi: 30 Mart 2017, Kabul tarihi: 11 Haziran 2017

Sorumlu yazar: Iş̧lay KARAŞAHIN YILDIRIM, e-posta:isilay.yildirim@tarim.gov.tr

\begin{abstract}
The effects of pre-storage UV-C illumination on fungal decay and postharvest quality of California Wonder type bell peppers were investigated. Fruits were exposed to UV-C dosages at 1.3, 2.4 and 3.6 $\mathrm{kJ} . \mathrm{m}^{-2}$ and stored at $8^{\circ} \mathrm{C}$ temperature with $90-95 \%$ relative humidity for 38 days. Untreated fruits were used as control. Changes in weight, titratable acidity, total soluble solids, decay and respiration rates of bell peppers were examined during storage. All UV-C dosages tested reduced the percentage of decay compared to control. Most promising UV-C dose was found to be as $3.6 \mathrm{~kJ} . \mathrm{m}^{-2}$ in controlling storage decays in bell peppers. Besides, respiration rate of control fruits were higher than those of irradiated bell peppers within $24 \mathrm{~h}$ at $20^{\circ} \mathrm{C}$. But, by the end of the 7 days at $20^{\circ} \mathrm{C}, \mathrm{CO}_{2}$ production rates were relatively similar.
\end{abstract}

Key words: Vegetable, pre-storage, physical treatments, quality, respiration

Hasat Sonrası Ultraviole-C (UV-C) uygulaması dolmalık biberlerde çürümeleri azaltır ve kaliteyi korur

\section{Öz}

California Wonder tipi dolmalık biberlerde depolama öncesi UV-C ışın uygulamasının mantarsal çürüklükler ve hasat sonrası kalite üzerine etkileri araştırılmıştır. Meyveler 1.3, 2.4 and 3.6 kJ.m-2 UV-C dozlarına maruz birakıldıktan sonra $8^{\circ} \mathrm{C}$ sıcaklıkta \%90-95 oransal nemde 38 gün süreyle depolanmışlardır. Uygulama yapılmayan meyveler kontrol grubu olarak kullanılmıştır. Depolama süresince ağırlıktaki, titre edilebilir asitlikteki, suda çözülebilir kuru maddedeki, çürüklükteki ve solunum oranındaki değişiklikler belirlenmiștir. Denenen tüm UV-C dozları kontrole göre çürüklük yüzdesini azaltmıştır. Dolmalık biberlerin depo çürüklüklerini kontrol etmede en ümit var UV-C dozunun $3.6 \mathrm{~kJ} \cdot \mathrm{m}^{-2}$ olduğu belirlenmiştir. Öte yandan, uygulamaların ardından ilk 24 saat içinde $20^{\circ} \mathrm{C}$ 'de bekletilen biberlerde kontrol grubuna ait meyvelerin solunum hızlarının UV-C uygulananlardan yüksek olduğu saptanmıştır. Ama, $20^{\circ} \mathrm{C}^{\prime}$ de bekletilen meyvelerin 7 gün sonundaki solunum hızları tüm uygulamalarda birbirine yakın olmuştur.

Anahtar kelimeler: Sebze, depolama öncesi, fiziksel uygulamalar, kalite, solunum

\section{Introduction}

In Turkey, bell pepper fruits (Capsicum annuum var. annuum) are one of the favorite crops for domestic market and export. On the other hand, peppers are highly perishable products, in particular during the postharvest life, high losses can occur due to fungal decays and senescence (Hudson et al., 1985). The development of fungi during postharvest transport and storage of horticultural products can cause great economic losses (Marquenie, 2002). Major fungal disease in postharvest phase of bell pepper is gray mould rot (Botrytis cinerea) (Ceponis et al., 1987). Pesticides are mostly used to control these decays (Eckert, 1991). Hence, the increased demand for pesticide-free commodities and restrictions on the use of chemical treatments, the use of chemical-free operations like heat and UV-C treatments have become more important (Klein and Lurie, 1991; 
Rodov et al., 1994). The use of a low dose(s) of UV-C light $(254 \mathrm{~nm})$ resulted in the reduction of storage rots of some vegetables like bell peppers (Mercier et al., 2001; Artes et al., 2006), carrots (Mercier et al., 2000), onions (Lu et al., 1987; Kasım and Kasım, 2012), spinach (Escalona et al., 2010), tomatoes (Liu et al., 1993; Barka, 2001; Liu et al., 2012), lettuce (Allende et al., 2006), fresh-cut zucchini squash (Erkan et al., 2001), UV-C and hot water combination in eggplants (Karasahin et al., 2005). Control of storage diseases by UV-C could result from induction of disease resistance as well as killing or inactivation of pathogens by irradiation (Mercier et al., 2001). On the other hand, pre-storage UV-C illumination could help delaying of fruit ripening by the reduction of ethylene synthesis and activity of cell-wall degrading enzymes (Maharaj et al., 1999). In yellow bell pepper pre-storage UV-C treatment at $6.6 \mathrm{~kJ} \cdot \mathrm{m}^{-2}$ dose reduced fruit softening and extended shelf-life (Promyou and Supapvanich, 2012). Previous studies about UV-C on different vegetable products conducted by Lemoine et al. (2007), Andrade et al. (2011), Pinheiro et al. (2016) showed that prestorage UV-C treated fruits had less weight loss than control fruits.

The objectives of this study were to investigate the possibility of controlling fungal decays and maintaining quality of stored bell pepper fruit with UV-C illumination.

\section{Materials and Method}

Mature-green California Wonder type bell peppers (cv. Jubilee F1) were harvested in February from a commercial greenhouse in Antalya, Turkey. These bell peppers were sorted for uniform size and color. They were divided into 4 different groups, 30 fruits were placed per boxes, 8 boxes per group, 4 boxes for determining decay $\%$ and weight loss, 4 boxes for chemical analysis were arranged. Three UV-C groups of bell peppers were irradiated with $1.3 \mathrm{~kJ} . \mathrm{m}-2,2.4$ $\mathrm{kJ} . \mathrm{m}^{-2}$ and $3.6 \mathrm{~kJ} \cdot \mathrm{m}^{-2}$ dosages, individually. Control group received no UV-C. Each UV-C treatment was replicated three times. UV-C treatment was performed in $(60 \times 150 \times 45 \mathrm{~cm})$ on-line illumination apparatus with ten lamps (Philips, model G15T8, 15 W). The peak wavelength emitted by the each lamp was $254 \mathrm{~nm}$. The processing line beneath the UV-C lamps consisted of rollers (50 cm in width) that rotates the fruit as it progresses. The speed of the rollers was adjusted by changing the speed of the motor that propelled it. The height of between UV-C lamps and processing line can be changed manually as needed. The UV-C fluency was measured with a UVX radiometer (UV products Inc., San Gabriel, CA) (Karasahin et al., 2005; 2006).

Fruits were exposed to UV-C dosages at 1.3, 2.4 and $3.6 \mathrm{~kJ} . \mathrm{m}^{-2}$. With the conveyor speed at $1.66 \mathrm{~m} . \mathrm{min}^{-1}$ and height with the $20 \mathrm{~cm}$ above the processing line 2 UV-C lamps delivered $1.3 \mathrm{~kJ} \cdot \mathrm{m}^{-2}$ and 7 UV-C lamps delivered $2.4 \mathrm{~kJ} \cdot \mathrm{m}^{-2}$. With the conveyor speed at 0.42 m. $\mathrm{min}^{-1}$ and height with the $24 \mathrm{~cm}$ above the processing line, $2 \mathrm{UV}$ lamps delivered $3.6 \mathrm{~kJ} . \mathrm{m}^{-2}$ (Karasahin et al., 2005; 2006). After UV-C treatments, irradiated and untreated control fruits were stored at $8^{\circ} \mathrm{C}$ temperature with $90-95 \% \mathrm{RH}$ for 38 days. Each fruit was numbered and weighed after UV-C irradiation. The result was expressed as percent weight loss. During storage period, UV-C treated and control fruits were examined for postharvest diseases. Fruit showing any sign of infection were removed from their box to avoid spread of infection to adjacent fruit. Decay incidence was expressed as the percentage of infected fruit. Titratable acidity (TA) and total soluble solids (TSS) content was determined on juice extracted from three replicates of ten fruit from each treatment. Acidity was determined by titrating $2 \mathrm{ml}$ of juice to $\mathrm{pH} 8.1$ with $0.1 \mathrm{~N} \mathrm{NaOH}$. Acidity was expressed as percentage citric acid. Percentage total soluble solid content was determined with hand refractometer. Respiration rates of bell peppers were measured as production of $\mathrm{CO}^{2}$. Weighed fruits were placed in 10 $\mathrm{L}$ jars per treatment with a continuous flow of humidified air at $20^{\circ} \mathrm{C}$ for 1 week. Respiration rates were measured everyday with modified colorimetric method of Pratt and Mendoza (1979). The results were calculated as $\mathrm{ml} \mathrm{CO}_{2} \mathrm{~kg}^{-1} \mathrm{~h}^{-1}$. The trials were arranged in a completely randomized factorial design. The factors were UV-C dosage and storage time. The results were submitted to a factorial analysis of variance and the mean values compared using Least Significant Difference test (LSD) at $\mathrm{p}=0.05$ (Nigro et al., 1998).

\section{Results and Discussion}

\section{Weight loss}

Depending upon the UV-C dosages weight loss of peppers increased progressively with extended storage (Table 1). After 38 days storage period the highest amount of weight loss was obtained 3.81\% from the $2.4 \mathrm{~kJ} \cdot \mathrm{m}^{-2} \mathrm{UV}-\mathrm{C}$ treated fruits and the lowest weight loss was obtained $3.14 \%$ from $3.6 \mathrm{~kJ} . \mathrm{m}^{-2} \mathrm{UV}-\mathrm{C}$ treated fruits. Fruits stored from 8 to 38 
days showed significant difference $(\mathrm{p} \leq 0.05)$ in weight loss between control and UV-C treated fruit with different dosages. Percentage weight loss was 2.59 for control, while it was 3.05 for $1.3 \mathrm{~kJ} . \mathrm{m}^{-2}$ and 3.30 for $2.4 \mathrm{~kJ} . \mathrm{m}^{-2} \mathrm{UV}-\mathrm{C}$ treated fruits during 38 days. The lowest value was observed in the $3.6 \mathrm{~kJ} . \mathrm{m}-2 \mathrm{UV}$ C treated fruits with $2.47 \%$. On the other hand, control with $2.59 \%$ weight loss was in the same statistical group with $3.6 \mathrm{~kJ} \cdot \mathrm{m}^{-2} \mathrm{UV}-\mathrm{C}$ treatment during storage (Table 1).

In this study, we report that UV-C treated bell peppers with 1.3 and $2.4 \mathrm{~kJ} . \mathrm{m}^{-2}$ doses had higher weight loss than control and $3.6 \mathrm{~kJ} . \mathrm{m}^{-2}$ UV-C treated fruits during cold storage. A slower weight loss rate is desirable from an economical point of view. In contrary, Sakaldas and Kaynas (2010) reported that UV-C treated green sweet bell peppers for 2.5 and 5 min and also, Promyou and Supapvanich (2012) suggested that UV-C illumination of yellow bell peppers in doses $2.2,4.4$ and $6.6 \mathrm{~kJ} \cdot \mathrm{m}^{-2}$ were reduced weight loss compared to control until 15 days storage. Pristijono et al. (2017) exposed $13.6 \mathrm{~kJ} \cdot \mathrm{m}^{-2}$ $\mathrm{UV}-\mathrm{C}$ doses to mature green tomatoes to test the effects of UV-C on postharvest quality during ripening. Results of their study showed that prestorage UV-C treatment did not significantly affect weight loss. Promyou and Supapvanich (2016), exposed mongoes to $6.6 \mathrm{~kJ} \cdot \mathrm{m}^{-2} \mathrm{UV}-\mathrm{C}$ dose and then stored at $12^{\circ} \mathrm{C}$ and $25^{\circ} \mathrm{C}$ for 16 days. The lowest weight loss was determined from untreated control fruits. In other study conducted by Maharaj et al. (1999), mature-green tomato fruit were irradiated with UV-C 3.7 and $24.4 \mathrm{~kJ} \cdot \mathrm{m}^{-2}$, and stored at $16^{\circ} \mathrm{C}$, under high relative humidity for a period of 35 days. Higher weight loss was found as $7.20,6.70$ and $5.50 \%$ for control, 3.7 and $24.4 \mathrm{~kJ} . \mathrm{m}^{-2}$ group respectively.

Table 1. Effects of different UV-C dosages and storage times on weight loss (\%) of bell peppers

\begin{tabular}{|c|c|c|c|c|c|}
\hline \multirow{2}{*}{$\begin{array}{c}\text { UV-C dosages } \\
\left(\mathrm{kJ} \cdot \mathrm{m}^{-2}\right)\end{array}$} & \multicolumn{4}{|c|}{ Storage Time (day) } & \multirow{2}{*}{ mean } \\
\hline & 8 & 18 & 28 & 38 & \\
\hline Control & 1.93 & 2.38 & 2.69 & 3.35 & $2.59 \mathrm{c}^{2}$ \\
\hline 1.3 & 2.62 & 2.71 & 3.08 & 3.77 & $3.05 \mathrm{~b}$ \\
\hline 2.4 & 2.62 & 3.25 & 3.53 & 3.81 & $3.30 \mathrm{a}$ \\
\hline 3.6 & 1.84 & 2.23 & 2.68 & 3.14 & $2.47 \mathrm{c}$ \\
\hline mean & $2.25 \mathrm{~d}$ & $2.64 \mathrm{c}$ & $3.00 \mathrm{~b}$ & & \\
\hline
\end{tabular}

z: Values marked with the same letter are not statistically different ( $\mathrm{p} \leq 0.05$ ), LSD (dosages):0.125, LSD (storage time): 0.125

\section{Titratable acidity}

At the beginning of storage an average content of $0.32 \%$ titratable acidity (TA) was determined in the bell peppers (Table 2). Titratable acidity (TA) decreased slightly with extended storage in all UV-C dosages. Over a period of 38 days there were significant differences in TA between control and different UV-C dosages $3.6 \mathrm{~kJ} \cdot \mathrm{m}^{-2}$ resulted in significantly lower values of TA with $0.25 \%$, although there were no significant differences between 1.3 and $2.4 \mathrm{~kJ} . \mathrm{m}^{-2} \mathrm{UV}-\mathrm{C}$ dosages, the highest values of TA detected with these dosages during storage period 0.32 and $0.31 \%$, respectively (Table 2). Generally, little change in titratable acidity was determined in all treatments during storage. Similar results were detected by Erkan et al. (2001) on UV-C treated zucchini squash slices.

\section{Total soluble solids (TSS)}

Results of TSS content of bell peppers are shown in Table 3. Percentage TSS for all UV-C dosages and control decreased as storage time increased. At the end of different storage periods statistically significant $(\mathrm{p} \leq 0.05)$ differences in TSS were found. At the beginning of storage TSS of bell peppers were $5.00 \%$, during 38 days TSS were decreased to $4.40 \%$. There was no significant interaction between TSS\% and UV-C dosages observed. Over 38 days storage period, TSS\% loss was significantly lower in $3.6 \mathrm{~kJ} . \mathrm{m}$ 2 UV-C irradiated fruits than other treatments (Table $3)$. Charles et al (2005), treated mature green tomato fruits with $3.7 \mathrm{~kJ} \cdot \mathrm{m}^{-2} \mathrm{UV}-\mathrm{C}$ and then stored fruits at $13^{\circ} \mathrm{C}$ for 21 days. They reported that there was no significant difference in total soluble solids between the UV-C treated and control fruits.

\section{Decay}

Depending upon the UV-C dosages the number of fruits showed decay increased progressively with extended storage (Table 4). At the end of different storage periods statistically significant $(\mathrm{p} \leq 0.05)$ differences in percent decay were found. 
Table 2. Effects of different UV-C dosages and storage times on titratable acidity (citric acid \%) of bell peppers

\begin{tabular}{|c|c|c|c|c|c|c|}
\hline \multirow{2}{*}{$\begin{array}{c}\text { UV-C dosages } \\
\left(\mathrm{kJ} \cdot \mathrm{m}^{-2}\right)\end{array}$} & \multicolumn{5}{|c|}{ Storage Time (day) } & \multirow{2}{*}{ mean } \\
\hline & 0 & 8 & 18 & 28 & 38 & \\
\hline Control & 0.32 & 0.33 & 0.29 & 0.27 & 0.25 & $0.29 \mathrm{~b}^{\mathrm{z}}$ \\
\hline 1.3 & 0.32 & 0.35 & 0.33 & 0.31 & 0.29 & $0.32 \mathrm{a}$ \\
\hline 2.4 & 0.32 & 0.31 & 0.31 & 0.31 & 0.30 & $0.31 \mathrm{a}$ \\
\hline 3.6 & 0.32 & 0.27 & 0.26 & 0.19 & 0.18 & $0.25 \mathrm{c}$ \\
\hline mean & $0.32 \mathrm{a}$ & $0.32 \mathrm{ab}$ & $0.30 \mathrm{~b}$ & $0.27 \mathrm{c}$ & \multicolumn{2}{|c|}{$0.26 \mathrm{c}$} \\
\hline
\end{tabular}

z: Values marked with the same letter are not statistically different ( $p \leq 0.05)$, LSD (dosages):0.019, LSD (storage time): 0.017

Table 3. Effects of different UV-C dosages and storage times on total soluble solids content (\%) of bell peppers

\begin{tabular}{ccccccc}
\hline UV-C dosages & \multicolumn{5}{c}{ Storage Time (day) } \\
\cline { 2 - 5 }$\left(\mathrm{kJ.m}{ }^{-2}\right)$ & 0 & 8 & 18 & 28 & 38 & 4.33 \\
\hline Control & 5.00 & 4.80 & 4.73 & 4.53 & $4.68 \mathrm{a}^{\mathrm{z}}$ \\
1.3 & 5.00 & 4.66 & 4.66 & 4.46 & 4.46 \\
2.4 & 5.00 & 4.66 & 4.60 & 4.73 & 4.53 & $4.71 \mathrm{a}$ \\
3.6 & 5.00 & 4.73 & 4.40 & 4.26 & 4.26 \\
\hline mean & $5.00 \mathrm{a}$ & $4.71 \mathrm{~b}$ & $4.60 \mathrm{bc}$ & $4.50 \mathrm{~cd}$ & $4.40 \mathrm{~d}$ \\
\hline
\end{tabular}

z: Values marked with the same letter are not statistically different ( $p \leq 0.05)$, LSD (dosages):0.118, LSD (storage time): 0.106

The percentage incidence of decay was less than $2 \%$ at during the first 8 days of storage and reached about $20 \%$ during 38 days. UV-C irradiation at all dosages reduced significantly $(\mathrm{p} \leq 0.05)$ fungal decay of bell peppers mainly caused by Botrytis cinerea and Alternaria alternata. A beneficial effect was also noted in fruit exposed to $3.6 \mathrm{~kJ} \cdot \mathrm{m}^{-2}$ dosage because no decay incidence observed in 8th day of storage compared to other treatments. Control fruit had $29.88 \%$ decay after 38 day of storage whereas the UV-treated peppers had $18.37 \%, 19.00 \%$ and $10.05 \%$ when the fruit were exposed to $1.3,2.4$ or $3.6 \mathrm{~kJ} . \mathrm{m}^{-2}$ of UV-C dosages respectively. During storage period decay after exposure to $3.6 \mathrm{~kJ} \cdot \mathrm{m}^{-2}$ of UV-C was significantly ( $\mathrm{p} \leq 0.05$ ) less than $(4.21 \%)$ after exposure to $1.3(8.96 \%)$ or $2.4 \mathrm{~kJ} \mathrm{~m}^{-2}$ (9.44\%) and control (15.75\%). Our studies indicate that it is feasible to treat vegetables online during processing with UV-C light for controlling postharvest decay
(Karasahin et al., 2005; 2006). These results those of other researchers (Wilson et al., 1997). In our study, all UV-C dosages $\left(1.3,2.4\right.$ and $3.6 \mathrm{~kJ} \mathrm{~m}^{-2}$ ) tested reduced the percentage of decay. The most effective UV-C dosage in controlling decay was $3.6 \mathrm{~kJ} \mathrm{~m}^{-2}$. The effect of UV-C on decay development of tomatoes inoculated with storage rot fungi was investigated by Liu et al. (1993). Also, effect of UV-C on reduction of the incidence of decay and lesion size for Rhizopus soft rot was observed at the optimum doses of 3.6 $\mathrm{kJ} . \mathrm{m}^{-2}$. Mercier et al. (2001) examined the effects of postharvest UV-C illuminations on decays of bell peppers during storage at $13^{\circ} \mathrm{C}$. They reported all doses $\left(0.22-2.20 \mathrm{~kJ} \cdot \mathrm{m}^{-2}\right)$ tested provided protection against natural infections. The reduction in decay might be related to the increase in decay-resistance of tissues due to the accumulation of antifungal compounds like phytoalexins (Mercier et al., 1993; Stevens et al., 1996; Wilson et al., 1994). Table 4. Effects of different UV-C dosages and storage times on decay incidence (\%) of bell peppers

\begin{tabular}{cccccc}
\hline UV-C dosages & \multicolumn{4}{c}{ Storage Time (day) } & \multirow{2}{*}{ mean } \\
\cline { 2 - 5 }$\left(\mathrm{kJ} . \mathrm{m}^{-2}\right)$ & 8 & 18 & 28 & 38 & $15.75 \mathrm{a}^{\mathrm{z}}$ \\
Control & 4.44 & 9.32 & 19.08 & 29.88 & $8.96 \mathrm{~b}$ \\
1.3 & 1.11 & 6.70 & 9.65 & 18.37 & $9.44 \mathrm{~b}$ \\
2.4 & 2.22 & 6.82 & 9.70 & 19.00 & $4.21 \mathrm{c}$ \\
3.6 & 0.00 & 2.22 & 4.55 & 10.05 & $19.33 \mathrm{a}$ \\
\hline mean & $1.94 \mathrm{~d}$ & $6.27 \mathrm{c}$ & $10.82 \mathrm{~b}$ & \multicolumn{2}{c}{} \\
\hline
\end{tabular}

z: Values marked with the same letter are not statistically different ( $p \leq 0.05)$, LSD (dosages):2.909, LSD (storage time): 2.909

\section{Respiration rate}

The respiration rate of unirradiated control fruits were higher than those of irradiated bell peppers within $24 \mathrm{~h}$ (Figure 1). After $48 \mathrm{~h}$, respiration in 1.3
$\mathrm{kJ} . \mathrm{m}^{-2} \mathrm{UV}-\mathrm{C}$ exposed fruits increased (4.74 $\mathrm{ml} \mathrm{CO}_{2} . \mathrm{kg}$ ${ }^{1} \mathrm{~h}^{-1}$ ) and remained slightly higher than other treatments. Generally, $\mathrm{CO}^{2}$ production declined in all treatments. By the end of the 7 days at $20^{\circ} \mathrm{C}, \mathrm{CO}_{2}$ production rates were relatively similar (Figure 1). 
In a study, Chinese kale (Brassica oleracea var. alboglabra) were treated with UV-C 1.8, 3.6, 5.4 and $7.2 \mathrm{~kJ} \mathrm{~m}^{-2}$ doses and stored at $20^{\circ} \mathrm{C}$. Results showed that UV-C reduced ethylene production and respiration rates (Chairat et al., 2013). In a study, fresh-cut zucchini squash fruits were exposed to UVC illumination for 1,10 or 20 minutes and slices were then stored at 5 or $10^{\circ} \mathrm{C}$. Influence of UV-C on respiration rates were detected at $20^{\circ} \mathrm{C}$ during 11 days. It was reported that UV-C treated slices had higher respiration rates than control zucchini squash slices (Erkan et al., 2001). These results were found to be more similar to ours.

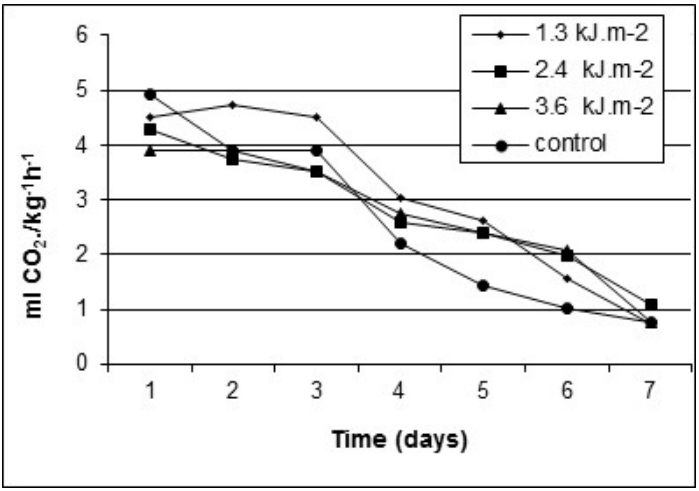

Figure 1. Effects of different UV-C dosages on respiration rates of bell peppers at $20^{\circ} \mathrm{C}$.

In conclusion, the research indicates that the greenhouse-grown 'Jubilee F1' bell peppers in Antalya region of Turkey can be stored successfully for a longer time at $8^{\circ} \mathrm{C}$ and $90-95 \% \mathrm{RH}$ if they are exposed to UV-C irradiation before storage. The most effective UV-C dosage in controlling decay was found to be $3.6 \mathrm{~kJ} . \mathrm{m}^{-2}$ in our results. It was determined that under these conditions this bell pepper cultivar can be stored for longer than 38 days without losing much of its quality.

\section{Kaynaklar}

Allende, A. McEvoy, J. Luo, Y. Artés, F., Wang, C., 2006 Effectiveness of two-sided UV-C treatments in inhibiting natural microflora and extending the shelflife of minimally processed 'Red Oak Leaf' lettuce. Food Microbiology, 23(3): 241-249.

Andrade, C.M.J., Vincente, A.R. Concellon, A., Chaves, A.R. 2011. Changes in red pepper antioxidants as affected by UV-C treatments and storage at chilling temperatures. LWT-Food Science and Technology, 44: 1666-1671.

Artés, F., Conesa, A., López-Rubira, V., ArtésHernández, F., 2006. UV-C treatments for improving microbial quality in whole and minimally processed bell peppers. The Use of UV as a Postharvest Treatment: Status and Prospects. Proceedings of the
International Conference on Quality Management of Fresh Cut Produce. In Ben-Yehoshua, S., D'Hallewin, G., Erkan, M., Rodov, V., Lagunas, M. (Eds.), ISHS, Leuven, Belgium, 12-17.

Barka, E.A., 2001. Protective enzymes against reactive oxygen species during ripening of tomato (Lycopersicum esculentum) fruits in response to low amounts of UV-C. Australian Journal of Plant Physilogy, 28(8): 785-791.

Ceponis, M.J., Capellini, R.A., Lightner, G.W., 1987. Disorders in fresh pepper shipments to the New York market, 1972-1984. Plant Disease, 71: 380382.

Chairat, B., Nutthachai, P., Varit, S., 2013. Effect of UV-C treatment on chlorophyll degradation, antioxidant enzyme activities and sensescence in Chinese kale (Brassica oleracea var. alboglabra). International Food Research Journal, 20(2): 623-628.

Charles, M.T., Kalantari, S., Corcuff, R., Arul, J., 2005. Postharvest Quality and Sensory Evaluation of UVTreated Tomato Fruit. Acta Horticulturae, 682: 537-542.

Eckert, J.W., 1991. Role of chemical fungucides and biological agents in postharvest disease control. In Biological control of postharvest diseases fruit and vegetables: Workshop Proceedings USDA ARS92:14-30.

Erkan, M., Wang, C.Y., Krizek, D.T., 2001. UV-C irradiation reduces microbial populations and deteriotion in Cucurbita pepo fruit tissue. Enviromental and Experimental Botany, 45:1-9.

Escalona, V.H. Aguayo, E. Martínez-Hernández, G.B., Artés, F., 2010. UV-C doses to reduce pathogen and spoilage bacterial growth in vitro and in baby spinach. Postharvest Biology and Technology, 56(3): 223-231.

Hudson, D.E., Butterfield, J.E., Lachance, P.A., 1985. Ascorbic acid, riboflavin and thiamin content of sweet peppers during marketing. Hortscience, 20:129-130.

Karasahin, I., Pekmezci, M., Erkan, M., 2005. Combined Hot Water and UV-C Treatments Reduces Postharvest Decay and Maintains Quality of Eggplants. 7th Fruit, Nut and Vegetable Production Engineering Symposium, Information and Technology for Sustainable Fruit and Vegetable Production, FRUTIC 05,

Karasahin, I., Pekmezci, M., Erkan, M., 2006. Combination treatments of hot water and UV-C reduces postharvest decay and maintains quality of bell peppers. COST 924 Working Group Meeting. The use of UV as a postharvest treatment: Status and Prospects. Antalya, Turkey. 29-33.

Kasım, R., Kasım, M.U., 2012. One Sided UV-C Treatments Maintain Quality of Fresh-Cut Green Onions. 
Journal of Agricultural Faculty of Uludag University, 24(1): 71-80.

Klein, J.D., Lurie, S., 1991. Prestorage heat treatments as a means of improving post-storage quality of apples. Journal of the American Society for Horticultural Science, 115: 265-9.

Lemoine, M. L., Civello, P..M, Martinez, G. A. Chaves, A.R. 2007. Influence of postharvest UV-C treatment on refrigerated storage of minimally processed broccoli (Brassica oleracea var. italica). Journal of Science, Food and Agriculture, 87: 1132-1139.

Liu, J., Stevens, C., Khan, V.A., Lu, J.Y., Wilson, C.L., Adeyeye, O., Kabwe, M.K., Pusey, P.L., Chalutz, E., Sultana, T., Droby, S., 1993. The effect of ultraviolet-C light on storage rots and ripenning of tomatoes. Journal of Food Protection, 56: 868-872.

Liu, C.H. Cai, L.Y. Lu, X.Y. Han, X.X., Ying, T.J., 2012. Effect of postharvest UV-C irradiation on phenolic compound content and antioxidant activity of tomato fruit during storage, Journal of Integrative Agriculture, 11(1): 159-165.

Lu, J.Y., Stevens, C., Yakubu, P., Lorcton, P.A., Eakin, D., 1987. Gamma, electron beam and ultraviolet radiation on control of storage rots and quality of Walla Walla onions. Journal of Food Processing and Preservation, 12: 53-62.

Maharaj, R., Arul, J. and Nadeau, P. 1999. Effect of photochemical treatment in the preservation of fresh tomato (Lycopersicon esculentum cv. Capello) by delaying senescence. Postharvest Biology and Technology 15: 13-23.

Marquenie, D., Michiels, C.W., Geeraerd, A.H., Schenk, A., Soontjens, C., Van Impe, J.F., Nicolai, B.M., 2002. Using survival analysis to investigate the effect of UV-C and heat treatment on storage rot of strawberry and sweet cherry. International Journal of Food Microbiology, 73: 187-196.

Mercier, J., Arul, J. and Cohen, C. 1993. Effect of UV-C on phytoalexin accumulation and resistance to Botrytis cinerae in stored carrots. Journal of Phytopathology, 139: 17-25.

Mercier, J., Roussel, D., Charles, M.T., Arul, J., 2000. Systemic and local responses associated with UVand pathogen-induced resistance to Botrytis cinerea in stored carrot. Phytopathology, 90(9): 981-986.

Mercier, J., Baka, M., Reddy, B., Corcuff, R., Arul, J., 2001. Shortwave ultraviolet irradiation for control of decay caused by Botrytis cinerea in Bell pepper: Induced resistance and germicidal effects. Journal of American Society of Horticultural Science, 126(1): 128-133.
Nigro, F., Ippolito, A., Lima, G., 1998. Use of UV-C light to reduce Botrytis storage rot of table grapes. Postharvest Biology and Technology, 13: 171-181.

Pinheiro, J. C., Alegria, C.S.M., Abreu, M.M.M.N., Gonçalves, E.M., Silva, C.L.M. 2016. Evaluation of alternative preservation treatments (Water Heat Treatment, Ultrasounds, Thermosonication and UV-C Radiation) to improve safety and quality of whole tomato. Food and Bioprocess Technology, 9(6): 924-935.

Pratt, H.K. and Mendoza, D.B., 1979. Colorimetric determination of carbon dioxide for respiration studies. HortScience, 14(2): 175-176.

Pristijono, P., Papoutsis, K., Scarlett, C.J., Bowyer, M.C., Vuong, Q,V., Stathopoulos, C.E., Golding, J.B., 2017. Postharvest UV-C treatment combined with 1methylcyclopropene (1-MCP), followed by storage in continuous low-level ethylene atmosphere, improves the quality of tomatoes. The Journal of Horticultural Science and Biotechnology, 1-9.

Promyou, S., Supapvanich, S., 2012. Effect of ultraviolet-C (UV-C) illumination on postharvest quality and bioactive compounds in yellow bell pepper fruit (Capsicum annuum L.) during storage. African Journal of Agricultural Research, 7(28): 4084-4096.

Promyou, S., Supapvanich, S., 2016. Physicochemical changes in 'Kaew Kamin' mango fruit illuminated with Ultra Violet-C (UV-C) during storage, Journal of Agricultural Science and Technology, 18: 145154.

Rodov V., Ben-Yehoshua, S., Fang, D., D’Hallewin, G., Castia, T., 1994. Accumulation of phytoalexins scoporone and scopoletin in citrus fruits subjected to various postharvest treatments. Acta Hortic. 381:517-524.

Sakaldaş, M., Kaynaş, K., 2010. Biochemical and quality parameters changes of green sweet bell peppers as affected by different postharvest treatments. African Journal of Biotechnology, 9:48, 8174-8181.

Stevens, C., Khan, V.A. ,Lu, J.Y. Wilson, C.L., El-Ghaouth, A., Chalutz, E., Droby, S., 1996. Low dose UV-C light as a new approach to control decay of harvested commodities, Chapter I. In: Pondolai, S.G. (Ed.) Recen. Res. Devel. in Plant Pathology. Research Signpost, India. 155-169.

Wilson, C.L., El-Ghaouth, A., Chalutz, E., Droby, S., Stevens, C., Lu, J.Y., Khan, V.A., Arul, J. 1994. Potential of induced resistance to control postharvest diseases of fruits and vegetables. Plant Dis. 78: 837-844.

Wilson, C.L., El-Ghaouth, A., Upchurch, B., Stevens, C., Khan, V.A., Droby, S., Chalutz, E. 1997. Using on-line UV-C apparatus to treat harvested fruit for controlling postharvest decay. Horttechnology. 7(3): 278-282 